\title{
EMERGENT IDENTITIES: THE CHANGING CONTOURS OF \\ INDIGENOUS IDENTITIES IN AOTEAROA/NEW ZEALAND
}

\section{E.S. Te Ahu Poata-Smith}

This chapter explores the changing contours of contemporary indigenous identities in Aotearoa/New Zealand. It challenges essentialist notions that Māori have “...singular, integral, altogether harmonious and unproblematic identities"(Calhoun 1994, 13). It will be argued that rather than conceptualising Māori identities as the continual transmission of fixed cultural essences through time, "being Māori" should be approached as part of a more discontinuous process in which culture and tradition are continually made and remade.

First, the chapter will present an overview of the way Mãori identities are signified and constructed through various codes and everyday practices, so that what it means to be Māori varies across space and time. Indeed, it will be argued that Māori identities are “...renewed, modified and remade in each generation. Far from being selfperpetuating, they require creative effort and investment" (Eller \& Coughlan 1993, 188). indigenous identities in Aotearoa/New Zealand are also constituted amid a flow of competing cultural discourses about what it means to be Māori. These identities are the outcome of interactions that involve claims made by individuals and groups to particular identities (and in some cases the rejection of those identities), and the ascriptions made by others (both from outside and within indigenous communities). As such, the negotiation and renegotiation of Māori identities is a contested process. It involves claiming and resisting identities from within a set of prevailing discourses about the authenticity of particular indigenous categories. 
Next, it will explore competing ideas and dominant narratives about what being Māori is, or what being Māori ought to be. It will examine, in the first instance, the idea that Māori identities should be understood principally in terms of "whakapapa" (the genealogical connections of individuals and groups to particular ancestors). Is whakapapa a sufficient criterion for those identifying as "Māori"? How significant are other social and cultural factors? In the second instance, the chapter will explore the impact of doctrines of "race" and racial purity on historical and contemporary notions of Māori identity in Aotearoa/New Zealand. How has the idea that being "Māori" is principally a matter of blood quantum (and that, by extension, the essence of "Maori" identity is a discrete set of phenotypical charateristics) shaped both indigenous and non-indigenous understandings of Māori identity?

Thirdly, it will trace the evolution of a sense of Māori "ethnicity" that transcends disparate iwi and hapu based identities. ${ }^{1}$ To what extent has a more generic notion of "Māori culture" become a critical dimension of contemporary expressions of Māori identity? How have these ethnic representations of Māori identity been embraced or resisted? Finally, the chapter will examine the argument that Māori identities are exclusively iwi or tribal in nature. To what extent do iwi constitute the permanent, timeless entities that are so often represented in contemporary debates about 'traditional' Māori social structures? Do they constitute the only authentic expression of being Māori?

\footnotetext{
${ }^{1}$ Iwi, hapū and whānau are the basic social units of Māori society and are based on descent from common ancestors. The word 'iwi' (literally meaning 'bone' but often miss-translated as 'tribe') refers to the widest of possible descent categories. 'Hapū' (literally meaning 'pregnant') constitute narrower descent groups made up of related 'whānau' (extended family groupings).
} 
The social actors that articulate these discourses are themselves embedded in unequal sets of social relations. It is important to emphasise that Māori identities have been, and continue to be, negotiated and renegotiated in the context of the ongoing political, economic, and social subjugation of iwi, hapū and urban Māori communities. Furthermore, the state has long been involved in the regulation and monitoring of indigenous identities in Aotearoa/New Zealand. Indeed, state agencies have actively encouraged Māori to adopt particular ways of identifying by categorising indigenous communities into more administratively convenient and allegedly authentic groupings (Poata-Smith 2004). Failure to express indigenous identities in these terms may undermine the credibility of those individuals and groups who resist such state sanctioned identity categories. On the other hand, there are real material and nonmaterial rewards associated with adopting categories of Indigeneity that are recognised by institutions of the state.

Māori identities are also shaped and molded in the context of inequalities between Māori that exist within iwi, hapū and urban Māori communities. As is the case with many subcultures and identity groups, definitions of authenticity are highly contested (Peterson 2005). The political debates and controversies are wide ranging and they reflect the radically different ways Māori life experiences have been shaped through the complex articulations and interpretations of racism, colonialism, ethnicity, class, and gender. Given the inequalities of wealth and political power that are entrenched within contemporary Māori society, particular historical representations and interpretations of "authentic" or "traditional" Māori identity have conflicting political implications for different groups of Māori in the present. There are, as a consequence, intense struggles over who gets to define that authenticity in the first place. Clearly, particular 
definitions of what constitutes authentic Māori ways of living favour the interests of some members over others.

The state has not been neutral in the ongoing political debates and controversies about Māori identities. In recent years, the complexity and fluidity of Māori identities and indigenous social and political relations have often been translated to fit more simplified, static, and essentialised cultural paradigms. In this way, the state has tended to privilege the representations of authenticity articulated by the more powerful members of iwi, hapū, and urban Māori communities in shaping identity categories often at the expense of those Mãori at the margins.

\section{The Concept of Identity}

Although there has been a "veritable discursive explosion" in the use of the concept of "identity" in the social and behavioural sciences, there has been a lack of consistency and clarity in its definition and application (Hall 1996). To some extent the wide variety of conceptualisations and definitions of identity simply reflect the concerns of different disciplinary paradigms with their own distinctive theoretical and empirical traditions. Nevertheless, the concept of "identity" has been deployed in such a myriad of ways, there is little agreement about the phenomena to which it might refer. As such, some scholars have argued that the concept of identity is so analytically loose and amorphous that it will never prove to be a reliable variable for the social sciences (Brubaker \& Cooper 2000). Others have attempted to develop greater analytical rigour and clarity by suggesting dimensions along which different meanings can be compared and contrasted (Hogg \& White 1995; Deauz 1996; Brewer 2001). 
While the diversity of Māori lived experiences is more widely acknowledged than it once was, there is a tendency, nonetheless, to fall back on reified and simplistic notions of tradition, language, and culture as constituting an unchanging "authentic" essence of Māori identity. Indeed, the underlying core of Māori collective identities are often characterised as if they are in some sense primordial or naturalistic and are frequently presented as being relatively unchanging and therefore transcending time and space. To some extent this response is understandable. As Calhoun has acknowledged, "When a particular category of identity has been repressed, delegitimated or devalued in dominant discourses, a vital response may be to claim value for all those labelled by that category, thus implicitly invoking it in an essentialist way" (Calhoun 1994, 202).

Indeed, more essentialist notions of Māori identity flourished with the rise of cultural nationalist strategies and the assumptions of identity politics as the dominant philosophical and political paradigm within Māori political movements from the late 1970s and early 1980s (Poata-Smith 1996). Cultural nationalist political ideology and practice rests explicitly on the assumption that there is an "essence" or set of innate and inherent characteristics that define Māori identity, and which have remained constant throughout history (see the discussion below).

While cultural nationalism is only one of a number of competing political ideologies that exist within the broader Māori political milieu, the representation of New Zealand history as an irredeemable clash of cultural identity based on underlying essentialist assumptions about Indigeneity have had a profound influence on contemporary debates about Māori identities.

Unfortunately, this has, all too frequently, gone hand-in-hand with the suggestion that those Māori that do not share all of these elements 
of culture, language, or tradition suffer some degree of deprivation or are inauthentic. Indeed, this points to one of the more problematic aspects of these essentialist conceptions of identity: that is, the tendency to posit one aspect of identity as the sole determinant constituting the social meanings of an individual's experience. Individuals, however, bear multiple identities. Māori life experiences, for instance, are also profoundly shaped by gender, sexuality, and class, among a host of other social factors. As such, Māori individuals have "...multiple intersecting social and identity attributes that help to comprise their self-identity" (Brekhus 2008, 1063).

Because of this, indigenous identity is best thought of as an ongoing social process rather than being a fixed property of an individual or group. At its core, this process involves a dialectical relationship between the way we attempt to present ourselves and the way that others regard us. In this sense, there is no external or objective source of validation, but ongoing identifying or positioning by social actors embedded in particular social systems ${ }^{2}$. The concept of identity deployed here, therefore, is not essentialist, but a strategic and positional. As Said $(1995,332)$ has argued, "Far from a static thing then, identity of self or of "other" is a much worked-over historical, social, intellectual, and political process that takes place as a contest involving individuals and institutions in all societies."

\section{Emergent Māori Identities}

For centuries Māori communities have communicated information about their identity, and their relationship to "space" and "place" in

\footnotetext{
2 See Hollway, W. (1984) "Gender Difference and the Production of Subjectivity" in Henriques, J., Hollway, W., Urwin, C., Venn, C. and Walkerdine, W. Changing the Subject, London: Methuen, pp. 227-263; Harre, R. and van Langenhove, L. (Eds.) (1999) Positioning Theory, Oxford: Blackwell.
} 
complex and dynamic ways. Their ongoing connection to a place of origin has manifested itself through complex forms of land tenure that embody the communities' changing material needs, land use patterns, belief systems, and governing structures (Jacobs \& Hirsh 1998). The use of the noun 'Māori' as a self-referential term and as a means to categorise and describe the indigenous inhabitants of New Zealand is, however, relatively recent in origin. ${ }^{3}$ As an adjective, the word "Māori" means "normal," "usual" or "ordinary" and was used historically to describe anything in its natural state. As an adverb, the word 'Māori' means "freely," "without restraint" and "without ceremony" (William 1992, 179).

Although there is some evidence that the term 'Māori' was in use prior to 1815 to describe the quality of being "native" or belonging to New Zealand, early European settlers, traders, and explorers invariably spoke of "Natives," "Aboriginals," or "Indians." These were, of course, well-rehearsed categories that had emerged as the lingua franca of European colonial encounters with indigenous peoples globally.

With the legal and statutory recognition of New Zealand as an independent sovereign territory outside British dominion in 1817, many colonial administrators, missionaries and settlers simply referred to the local inhabitants by the more generic label "New Zealanders". This became more problematic with the annexation of New Zealand as a formal British settler colony in 1840 and the subsequent rapid influx of predominantly British settlers. The term "New Zealander" would no longer remain the preserve of indigenous communities.

\footnotetext{
${ }^{3}$ Historically, “Tangata Māori” was a phrase used to differentiate human beings from supernatural beings.
} 
From the mid-nineteenth century, the word "Māori" was increasingly used as a noun to differentiate the indigenous inhabitants of Aotearoa/New Zealand from the new European arrivals (Williams 1971, 179). One of the earliest documented examples of the use of the word 'Māori' in this way, in written English, dates from the 1850s. ${ }^{4}$ In this sense, the notion of a "Māori race" or people co-existed with and eventually superseded other official British Colonial Office descriptors employed in the New Zealand context (although the more pejorative and widely used "Native" continued to be employed in official State business). In fact, it was not until 1947 with the introduction of the Mãori Purposes Act that the Department responsible for the administration of indigenous affairs in New Zealand changed its nomenclature from the Department of Native Affairs to the Department of Māori Affairs.

Being "Māori" was, in a sense then, created through that very contact with members of European settler groups. It was a convenient category that did not require a more nuanced understanding of localised identities and relationships based around whānau, hapū and iwi. Since the nineteenth century, the term "Mãori” has been invested with new meaning and significance. Indeed, contemporary Māori identities have been constituted amid a flow of competing cultural discourses about what it means to be a member of iwi, hapū and/or urban Māori communities. The negotiation and renegotiation of contemporary Māori identities is a contested process in the sense that it involves claiming and resisting identities from within a set of

\footnotetext{
${ }^{4}$ Cooper, G.S. (1851) Journal of an expedition overland from Auckland to Taranaki by way of Rotorua, Taupo, and the west coast undertaken in the summer of 1849-50 by his Excellency the Governor-in-Chief of New Zealand, Auckland: Printed by Williamson and Wilson, p. 204.
} 
prevailing discourses about the authenticity of particular Indigenous categories.

\section{Whakapapa}

Māori identities in Aotearoa/New Zealand have been, and continue to be, expressed principally in terms of "whakapapa" (the genealogical connections of individuals and groups to particular ancestors). Whakapapa not only refers to lines of descent that bind people to ancestors and to each other, but constitutes a framework that links human beings to the origins of the universe and all animate and inanimate phenomena. The notion of "whakapapa" (geneaology) may have been derived from the Māori verb to "place in layers" or "lay one upon another" (William 1992, 259). As Apirana Ngata $(1972,6)$ once explained it, whakapapa is "...the process of laying one thing upon another. If you visualise the foundation ancestors as the first generation, the next and succeeding ancestors are placed on them in ordered layers."

Those who trained as repositories of oral history could recite hundreds of names in interlocking genealogies. As Ballara (1991, 550551) notes:

Evidence exists that the most expert tohunga did have phenomenal memories... There is some evidence that genealogies were learned in metric patterns involving changes of pitch for each generation, similar to intonation of waiata, in formalised patterns designed to aide the memory...Genealogies were often rendered at a speed and in a tone of voice designed to protect both the tapu information and the status of the tohunga.

Although the emphasis on the oral retention of whakapapa has been maintained, the development of writing in Māori communities has meant that whakapapa and its associated knowledge have also been 
recorded in manuscripts and books. Strict protocols exist around the handling of such manuscripts.

The critical feature of whakapapa is that an individual's identity was primarily defined and given meaning through their relationships with others. The emphasis was on social connectedness. This was expressed in whakatauākī and pepeha (proverbs or sayings) and in waiata (songs) and pūrākau (historical narratives). These declarations not only consolidated relationships with ancestors and the natural environment, they also served to differentiate Māori on the basis of distinctive hapū and iwi.

Historically, as Taonui (2011) points out, whakapapa “...did not list all individuals, marriages and tribes, but focused on those that were important and relevant for the time." Indeed, whakapapa was crafted in different ways to suit different situations and contexts. Ngata, for example, identified a number of variations in the form that whakapapa could take: "taraere" involved the recitation of a single line of descent from an ancestor, without the inclusion of marriages or other kin; "whakamoe" traced descent from an ancestor and included the marriages and subsequent kin; "tahu" set out the main descent lines for an iwi or hapū; "whakapiri” were used to define a person's position in respect of another on the basis of their seniority in the descent line.

For this reason, whakapapa took on different forms for different audiences and purposes. As Te Rito $(2007,2)$ has observed:

The technique of tararere is particularly useful when dealing with the names of ancestors where little is known of spouses and other lateral links. As we come closer to modern times the techniques of whakamoe and of whakapiri become particularly useful, as the knowledge of lateral ancestors like spouses, is more to the forefront of people's memories. Their stories are better remembered and the 
narratives become easier to fill out. In other cases, for ease of presentation, the whakapapa can be displayed laterally rather than vertically. This method is suitable for example when there are multiple spouses.

Where only main or key ancestors are shown, the technique of tahu is suitable. This technique is also suitable in other cases, for example when some siblings may be more well- known than others for their deeds and may consequently have a high profile, while others may have died as babies on the other hand and consequently be lesser known. Furthermore, with large families it is often quite difficult to represent all its members within the confines of the written page as the whakapapa charts can easily become quite cluttered and cumbersome to manage.

Although whakapapa is commonly viewed as the most fundamental feature of being Māori today, it is clear that there is not necessarily a direct correspondence between whakapapa and identifying as "Māori" in contemporary New Zealand society. The New Zealand 1996 Census of Population and Dwellings is particularly revealing in this regard. Using separate questions, the census required respondents to identify the ethnic group(s) to which they belonged to as well as whether they were of Māori descent. Question 10 of the 1996 Census allowed respondents to select more than one ethnic group (of which, "NZ Māori" was one of a number of possible ethnic categories). In addition, Question 13 asked respondents whether they were, “...descended from a NZ Maori (that is, did you have a NZ Maori birth parent, grandparent, or great-grandparent, etc.)?" 579,714 people, or 17.3 percent of the New Zealand population on census night, said they were of Māori descent. Of those people who said they were of Māori descent, 84.7 percent also identified with the Māori

\footnotetext{
${ }^{5}$ Statistics New Zealand (1998), 1996 New Zealand Census of Population and Dwellings: Iwi, Wellington: Statistics New Zealand.
} 
ethnic group. The fact that 15.3 percent of respondents claimed to be descended from a NZ Māori but did not identify as Māori in an ethnic sense, demonstrates that while whakapapa may be an essential requirement it is not necessarily sufficient by itself.

This trend was repeated at the last Census of Population and Dwellings in 2006, which also distinguished between those claiming Māori descent (who numbered 643,977 or 17.7 percent of the population usually living in New Zealand), and those actually identifying themselves as Māori $(565,329)$.

There are clearly a range of other factors which appear to influence an individual's decision to identify as Māori as opposed to simply declaring that one's ancestors were Māori. Anecdotally, an individual's cultural background, proficiency in the Māori language, the influence of popular ideas around 'race' (and perhaps the legacy of ideas about 'racial purity'), the strength of an individual's ties to iwi and hapū, and the intensity of ethnic attachments ${ }^{6}$ appear to be significant factors. In this way, even in situations where whakapapa is established, there may be intense debates over how to determine the depth or authenticity of an individual's identity. Was the individual raised within their tribal territory? Were they immersed within the tikanga of their hapū and/or iwi? Do they speak Māori? Claims to Māori identities based on these more essentialist, "traditional" markers tend to be given more weight in the broader discursive milieu.

\footnotetext{
${ }^{6}$ At the 2006 Census, 42.2 percent of Māori stated that they also identified with European ethnic groups, 7.0 percent with Pacific peoples ethnic groups, 1.5 percent with Asian ethnic groups, and 2.3 percent also gave 'New Zealander' as one of their ethnic groups.
} 
Rāwiri Taonui (2011) describes a number of new expressions that have evolved in the context of contemporary debates about Māori authenticity. For example, the phrase "born-again Māori" is employed pejoratively to describe those Māori who are usually of mixed descent and who may not have previously acknowledged their identity as Māori. There is sometimes an implicit assumption that those Māori have emerged at a time when the rewards and opportunities associated with being Mãori were greater, but were conspicuously absent in the struggle against racism and prejudice, which came at a considerable personal cost to many individuals and families. The phrase also indicates a tension over the idea that Māori identities can be voluntary. In other words, the prevailing notions of authenticity are more hostile towards the idea that one can be Māori as matter of choice at a particular time and place, rather than being Māori in an inherent and involuntary sense.

A related term, "plastic Māori" (i.e. meaning ersatz and therefore inauthentic), is a term sometimes used by cultural nationalists to refer to those Māori who do not possess an understanding or proficiency in te reo Māori (Māori language), or a knowledge of tikanga (cultural protocols) and whakapapa (geneaology). These Māori are often viewed as "de-cultured" and "assimilated". They are frequently depicted as hapless victims of colonisation, intoxicated by the material trappings of 'Pākehā $\bar{a}^{7}$ society' and alienated from their true identities.

In addition, the terms "waka blondes" and "kōtuku mā" (white herons) are used to describe Māori who possess what are considered "non-traditional" phenotypical features such as fair skin and/or hair colouring, and blue or green eyes. It is important to emphasise that these terms are not necessarily used in a pejorative sense within Māori

\footnotetext{
${ }^{7}$ Pākehā is the Māori language term used to refer to New Zealanders who are the descendants of British settlers.
} 
communities. Indeed, the validity or authenticity of these identities will more often than not rest on other cultural and social factors. Nevertheless, assumptions about the physical characteristics and traits associated with being Māori continue to shape social interactions in wider New Zealand society. Furthermore, those who are unable to project these identifiable biological traits and stereotypes, find other ways of activating and performing their Indigeneity in the course of interactions with others.

\section{The Idea of 'Race' and the Biological Categorisation of Māori}

The idea of "race" and the notion of blood quantum have profoundly shaped both historical and contemporary notions of Māori identity in Aotearoa/New Zealand. Official State policies with respect to Mãori were strongly influenced by ideas about racial purity, social Darwinism, and the assimilative paradigms of New Zealand nationalism.

Racial policies were, however, applied inconsistently and often in a contradictory fashion. On the one hand, Māori were frequently represented as "noble savages," a term associated with a romanticised depiction of indigenous peoples as living a life of harmony uncorrupted by the excesses of Western industrial life. On the other hand, Māori were consistently represented as "racially inferior" to their European counterparts. These views were well rehearsed on a global scale. Indeed, the alienation of the lands and resources of indigenous peoples was justified as part of the "natural" evolutionary process. It demonstrated the inherent superiority of the colonising 'races' and the inferiority of the colonised.

A significant decline in the Màori population by the later part of the nineteenth century seemed to lend credence to social Darwinist notions of the "survival of the fittest." The rapid influx of European 
migrants, recurrent epidemics, high infant mortality, and declining resources as a result of land alienation saw Māori “...relegated to a precarious existence on the fringe of a rapidly expanding Pakehadominated state" (Pearson 1990, 57). By the turn of the twentieth century, Māori-who had been the numerical majority in around 1860 -were a mere four percent of the total New Zealand population. In the colonial imagination, this was simply the inevitable consequence of a clash of superior and inferior "races."

The Māori population began to recover by the early twentieth century. Nevertheless, few disputed the inevitability of assimilation as a priority for state policy. For this reason, the children of Māori and Pākehā unions were often depicted in a more positive light. As well as the apparently more favourable aesthetic qualities associated with "halfcaste" children, they were also said to personify the "dilution" of a potent "Maori" essence that was resistant to assimilative pressures. In other words, being Māori was a contaminating factor that could be bred out of existence or, with an administrative sleight of hand, categorised out of existence. Those who were categorised as being less than "half" blood could be "salvaged" because their "white blood" was their springboard to successful assimilation.

For this reason, in addition to distinguishing "half-caste Māori" from "full-bloods," a further distinction was drawn between half-castes whose mode of living was Māori, and those who lived as European. ${ }^{8}$ After the 1921 census, the lifestyle distinction between MāoriEuropean half-castes was discarded and all half-castes were statistically assigned to the Mãori population. At the same time the concept of blood quantum was extended from half-caste to embody a

\footnotetext{
${ }^{8}$ See Kukutai, T.H. (2010), 'The Thin Brown Line: Re-Indigenizing Equality in Aotearoa New Zealand', Unpublished PhD Thesis, Stanford University
} 
wider range of racial designations including "three-quarter-caste" and "quarter-caste."

Of course, notions of "race" and "racial purity" were tied up with political rights and entitlements. Until the passing of the Māori Affairs Amendment Act in 1974, a Māori was defined as someone with "half or more blood". From 1896 up until 1967, Māori (except "half-castes") were not allowed to stand as candidates in European seats. Until 1975, only so-called "half-castes" were allowed to choose whether they voted in the General Electorates or the Māori Electorates. In 1975 the Labour government introduced a "Māori electoral option", to be held alongside (or following) each census. This also allowed electors of Māori descent to choose whether they enrolled in general or Māori seats.

The idea that being "Māori" is principally a matter of blood quantum (and that, by extension, the essence of "Maori" identity is a discrete set of phenotypical characteristics) still influences many popular understandings of contemporary Māori identities. As Tūhoe scholar, Tracey McIntosh (2001) notes:

I have been asked many times why I self-identify as Maori, the underlying thrust of the inquiry being less posed as an inquiry of interest but rather offered as a challenge; that is, a questioning of the authenticity of my claim. My authenticity is questioned due to the simplest of things: colour. Being of fair complexion means that for many my persistence to identify as Maori is seen by some (nonMaori) as a form of romantic stubbornness while for others it is seen as merely perverse.

The notion that the "racial essence" of Māori has been increasingly eroded after two centuries of contact, and that there are now no "real" (that is, "racially pure") Māori left in New Zealand, has been firmly entrenched in the public's consciousness. This is, of course, a very 
convenient justification for ignoring indigenous grievances. If there are no "real Māori" then there is no need to confront the colonial atrocities of the past and the continued marginalisation of indigenous communities in the present.

In the context of the assimilative pressures of New Zealand nationalism, to claim a Māori identity when one should simply "pass" as Pākehā is often represented as an intentionally divisive act. With its direct appeal to national interest, the infamous catch cry, "we're all New Zealanders" has frequently been employed to deny legitimacy to Māori struggles for the return of land, a greater share of society's resources and an active role in formal decision-making processes. The mythology of "one people, one nation" has been the bedrock of the assimilative ideologies that have underpinned government policy with respect to Māori for well over a century.

\section{The Politicisation of Māori Ethnicity}

From the 1970s onwards, there was a gradual shift in the New Zealand based social science literature from an emphasis on "race" and biology to a concern with culture and "ethnicity." Although, blood quantum continued to be used as a way of measuring identities in the official New Zealand Census until 1981, the emphasis on ethnicity was part of a growing critique of the idea of "race" and the notion that biological racism (at least in its more explicit forms) was politically and morally disreputable. It led many social scientists to search for more positive, self-defined and empowering ideologies. This took place in the context of the politicisation of "ethnic" identities in response to racism and the legacy of colonialism. It was an integral part of a more generalised upsurge in struggle which included anti-colonial movements in the so called "third world," national liberation struggles against Western imperialism, the civil rights movement in the United States, the proliferation of a variety of social movements (anti-war 
movements, the women's liberation movement, environment movements, gay and lesbian rights movements, and so forth), and the struggles of indigenous peoples on a global scale.

Since the late 1960s, one of the critical features of the evolving ideology of Māori political activism was an emphasis on the positive aspects of being 'Māori' in an attempt to unite diverse Māori communities in struggle. The construction of a contemporary Māori ethnic identity has been a contested social and political process that has involved the selective reconstruction of symbols and beliefs from the past and their adaptation to the contemporary political environment (Poata-Smith 2001). This centrally involved the conscious employment of ideological constructs that replaced the more innocuous and apolitical term "Polynesian." Specifically, it involved using the language employed by black power movement in the United States. This generated an aggressive and assertive meaning to being Māori or "black." As an ideological construct, black implied a resistance to white values, social structures and institutions and represented an inherent commitment to alternative aesthetic standards (Greenland 1991, 98). It emphasised the inherent polarity of Māori and Pākehā world views.

This assertive concept of being Māori involved an individual reaction against the racist assumptions of New Zealand society which found expression even when it came to personal appearance: aesthetically, the way forward for individual Māori had often seemed to be straightening their hair and lightening their skins. This was rejected fundamentally with an unabashed expression of "Māoriness" through hairstyle, dress codes, behavior, and name changing to reflect more "authentic" Māori identities. Greenland $(1991,99)$ notes that such a challenge to the conventional and traditional categories of Māori identity propagated a sense of collective identity and solidarity in 
struggle which transformed the attributes of phenotype into "...an overt semiotic combat."

It is important to appreciate that this symbolic construction of a paniwi "ethnic solidarity" compensated for the absence of other more localised and regional identifications (particularly te reo Māori and tikanga), which had united preceding generations of Māori on the basis of iwi and hapū. Despite the perceived loss of traditional authenticity, the physical expression of ethnic solidarity performed the function of maintaining a distinctive "Māori identity" which differentiated itself culturally and politically from the bilingual Pacific migrants who had maintained a national homeland and cultural protocols the likes of which had not been passed on to the post-1950s Māori generation.

The development of the idea of a Māori community united in resistance by virtue of their common ethnicity drew on and influenced revisionist accounts of colonisation and Māori resistance that were emerging within academia (Sharp 1990, 4). Revisionist accounts of New Zealand history demonstrated the unique nature of Māori politics and made available accounts that depicted the exploitative nature of colonisation and the active role of Māori in response. ${ }^{9}$ These historical accounts established an interpretation of history incompatible with popular myths such as the view of colonialism as the "white man's burden" and of New Zealand as a "one people

\footnotetext{
${ }^{9}$ For example see, T. Simpson, Te Riri Päkehä: The White Man's Anger, Auckland: Hodder and Stoughton, 1986. D. Scott, Ask that Mountain: the Story of Parihaka, Auckland: Reed/Southern Cross, 1981. A. Ward, A Show of Justice; J. Binney, et al. Mihaia; J. Belich, The New Zealand Wars; C. Orange, The Treaty of Waitangi; M.P.K Sorrenson, “Towards a Radical Reinterpretation of New Zealand History: the Role of the Waitangi Tribunal", pp. 158-178; J. Kelsey, "Legal Imperialism and the Colonization of Aotearoa”, pp. 20-43.
} 
nation." They debunked the view of the Treaty of Waitangi as a sacrament of harmonious ethnic relations and a symbol of peaceful coexistence. These revisionist narratives also gave powerful coherence to contemporary struggles for Māori autonomy by linking them to historical traditions of resistance in a way that transcended disparate iwi and hapū experiences of everyday life.

The tangible symbol that united past, present, and future generations of Māori was the land. Indeed, the historical fact of land alienation provided a rallying symbol and focus for protest providing a contemporary basis for pan-tribal unity. ${ }^{10}$ During the land rights movement of the 1970s, land alienation became the central political and historical feature that underpinned all others. Greenland (1991, 93-94) identifies three ideological themes that were developed in this regard. The first theme emphasised the inherent polarity between two allegedly conflicting approaches (Māori and Pākehā) to land: one emotive and communal, the other material and individualistic, one natural and environmental, the other artificial and exploitative. The gap between Māori and Pākehā conceptions of land was irredeemable and the political significance of this was crucial to the demands of the activists. The second dimension emphasised the notion of tāngata whenua (people of the land), “...the common origin and fundamental unity [of all Māori] based on an organic primordial connection with the land" (Greenland 1991, 94).

The third theme posited a link between a variety of contemporary social problems such as alcoholism, unemployment, lower life expectancy, psychological illness, high rates of imprisonment,

\footnotetext{
${ }^{10}$ See Poata-Smith, E.S. Te Ahu (1996) 'He Pōkeke Uenuku i Tu Ai: The Evolution of Contemporary Māori Protest', in Spoonley, P., Pearson, D. and Macpherson, C. (eds) Ngā Patai: Racism and Ethnic Relations in Aotearoa/New Zealand, Palmerston North: Dunmore Press.
} 
violence, and poverty to the historical fact of land alienation (ibid.). The fact of land alienation provided a concrete link between everyday political struggle and the all-embracing political attack on "Pākehā society."

The assumption that there is an 'essence' or set of innate and inherent characteristics that define Māori and Pākehā identity, which have remained constant throughout history, underpins Māori cultural nationalist political ideology and practice. For instance, Pākehā are said to embody inherent characteristics: they are competitive, exploitative, and value material success (Greenland 1991, 97). Māori communities on the other hand, are said to be co-operative and communal, reflecting the importance of the collective will of the people and their natural relationship with the environment.

The emphasis on the rediscovery of "culture" as a panacea to the issues confronting contemporary Māori communities continues to have a significant impact on arguments about the authenticity of Māori identities. The revitalisation of te reo Māori (the Māori language) is frequently at the heart of this process. The argument that the significance of Māori cultural paradigms can only be comprehended through immersion in Māori language, and by extension, that te reo Māori is a fundamental feature of authentic Māori identities, has been an influential narrative.

In this regard, researchers and public policymakers have sometimes uncritically accepted essentialist notions of authenticity. This is particularly the case for research that focuses on the measurement of Māori cultural identity or ethnic group attachment. For instance, the "Best Outcomes for Māori: Te Hoe Nuku Roa" project is a 25-year longitudinal study of Māori households run by the Research Centre for Māori Health and Development and Te Pūtahi-ā-Toi, the School 
of Māori Studies at Massey University. ${ }^{11}$ The study involves 700 Māori households and is based on the development of a "Māori relevant" framework to gauge personal and family development. ${ }^{12}$ The study proposes a measure of Māori identity which places the highest weighting on Māori language and is followed by "involvement in extended family," "knowledge of ancestry," and "self-identification." The fact that Māori language is weighted so heavily as an indicator of Māori identity is interesting given the lack of fluency that exists amongst contemporary Māori. Indeed, the National Māori Language Survery shows that, “...although 59\% of Māori adults speak the Māori language to some extent, the majority (83\%) have either low fluency or do not speak Māori at all. Most Māori adults said that they found English the easiest language to converse in. Only 8\% of Māori adults are highly fluent...". ${ }^{13}$

This is not to suggest that Māori language is not a valuable and important dimension in the lives of many Māori, nor that communities should not invest in its revitalisation. What it does reveal, however, is the influence of certain essentialist assumptions about the relationship between Māori language and claims of authenticity. Such weightings privilege the narratives of more powerful and influential members of Māori communities while

\footnotetext{
${ }^{11}$ See Forster, M. (2003). Te hoe nuku roa: A journey towards Māori centered research. Ethnobotany Research \& Applications, 1, 47-53; Cunningham, C., Stevenson, B., \& Tassell, N. (2005). Analysis of the charaterictics whānau in Aotearoa. Wellington: Massey University, Ministry of Education.

${ }^{12}$ See Best Outcomes for Māori: Te Hoe Nuku Roa http://www.tehoenukuroa.org.nz/about_us.htm

${ }^{13}$ Te Puni Kōkiri, Te Taura Whiri i te Reo Māori, and Statistics New Zealand (1998),Te Mahi Rangahau Reo Māori: The National Māori Language Survey, Wellington, p.10.
} 
disregarding or ignoring the lived experiences and views of other members.

\section{Iwi}

Some have responded to the evolution of a sense of Māori ethnicity by claiming that it represents an "invention of tradition" that is not a natural product of an essentially tribal people. ${ }^{14}$ The idea that authentic Māori identities are essentially iwi-based identities has been articulated by a number of prominent Māori leaders. Sometimes such an argument involves a suspicion about the State's historical encouragement of pan-tribalism and the cultural homogeneity that is implicit in the concept of "Māori ethnicity."

In one of the first collection of articles on Māori issues published by Māori authors in the mid-1970s, Tūhoe kaumātua (elder), John Rangihau (1992, 190) wrote of his:

faint suspicion that Maoritanga is a term coined by the Pakeha to bring the tribes together. Because if you cannot divide and rule, then for tribal people all you can do is unite them and rule. Because then they lose everything by losing their own tribal histories and traditions that give them their identity.

Rangihau (ibid.) famously described the centrality of iwi to any articulation of Māori identity:

My being Maori is absolutely dependent on my history as a Tuhoe person as against being a Maori person. It seems to me there is no such thing as Maoritanga because Maoritanga is an all-inclusive term which embraces all Maori. And there are so many different aspects

\footnotetext{
${ }^{14}$ See for example the comments made by Sir Tipene O'Regan, in H. Melbourne (ed), Māori Sovereignty: The Maori Perspective, Hodder Moa Beckett, 1995, pp. 153-165.
} 
about every tribal person. Each tribe has its own history. And it's not a history that can be shared among others. How can I share with the history of Ngati Porou, of Te Arawa, of Waikato? Because I am not of those people. I am a Tuhoe person and all I can share in is Tuhoe history.

An iwi based identity may also provide a powerful sense of legitimacy for those who are not ascribed a Māori identity by outsiders. For example, Kai Tahu leader, Tipene O'Regan, who is of both Irish and Māori descent, recalls getting caught up in an argument between a Ngāti Porou and Te Arawa colleague, and being told to:

butt out on the basis that I wasn't a Maori. I was nothing but a Pakeha with a whakapapa...I remember sitting there as if a flash of revelation had come upon me. I was thrilled. I said, 'You are absolutely right. I am not a Maori. I'm Ngai Tahu!' I knew, when I said that, that no one could define it except me and my kin group, my iwi!" (Melbourne 1995, 156)

The contemporary emphasis on the iwi as the basic social and political organisational unit of Māori society is, in part, a product of the Treaty of Waitangi claims process to settle historical grievances and the continuing influence of hierarchical and static models of Māori social and political organisation that underlie popular accounts of the past (Poata-Smith 2004).

Since the 1990s, the state has increasingly recognised those iwi that have been restructured as corporate entities as the official representative structures of contemporary Māori society, and the appropriate bodies for managing the hundreds of millions of dollars worth of assets that would flow from compensation deals with the Crown. The growing number of references in state policy documents to tribal formations re-conceptualised in this way, has entrenched the idea that Māori rights under the Treaty of Waitangi (apart from those 
of equal citizenship) accrue exclusively to iwi who are guaranteed sole rights to the resources within their takiwà (territory). This systematic privileging of iwi as the principal beneficiaries of Treaty settlements has also been reinforced by the courts. ${ }^{15}$

Although it is widely acknowledged that the Treaty of Waitangi settlements should ultimately benefit all Māori, there is growing concern that Māori individuals and groups who (a) are uncertain of their iwi origins; (b) have weak associations with their iwi; (c) live outside their tribal takiwā (territory); or (d) choose to live and work in an urban environment, may encounter difficulty in directly participating in benefits distributed through iwi. In the context of the prolonged litigation brought against the Fisheries Commission by urban Mãori authorities challenging the allocation of assets solely to iwi on the basis that they were the traditional "tribes," some have seen urban Māori as harbingers of destruction for "authentic" or "traditional" sources of Māori political authority (Robertson 1997, 5).

Nevertheless, iwi are not the permanent, timeless entities that are often presented in popular accounts of the past. Māori social and political relations were, in fact, far more dynamic and flexible than is generally conveyed. Unfortunately, many tribal histories have uncritically accepted, and sometimes perpetuated, ethnological accounts that were based on the notion that iwi were "contiguous principalities" or discrete kingdoms ruled over by "principal chiefs." To some extent, these developments reflect the influence of colonial administrative paradigms that attempted to codify the complexity and fluidity of Māori land tenure and social and political relations and

\footnotetext{
${ }^{15}$ Treaty of Waitangi Fisheries Commission, Ahu Whakamua -Report for Agreement: A Report by the Treaty of Waitangi Fisheries Commission on the Allocation of Assets and Distribution of the Fisheries Settlement, Wellington: Treaty of Waitangi Fisheries Commission, August 2002, p. 26.
} 
translate it into a more simplified and truncated hierarchy of single "tribes" with politically subordinate sub-divisions. It also reflects the influence of the Native Land Court, as judges and assessors redefined features of the traditional Māori social and political organisation and forced it to conform to a preconceived legal order based on capitalist private property and the ownership of discrete territories by iwi (Parsonson 1992, 190-194).

These notions were, of course, especially attractive to officials looking for an easily identifiable, all-embracing, and authoritative body with which to negotiate land purchases. The projection of this static and hierarchical paradigm into pre-colonial history, however, is fundamentally problematic. As Ward $(1993,202)$ emphasises:

the supposedly neat hierarchy of whanau, hapu, and iwi, with its rangatira and its ariki (a tidy pyramidal model which still gets trotted out in anthropology and sociology that feeds upon previous publication rather than undertaking original research or checking the most recent writings) was not actually like that.

Indeed, while ethnological reconstructions of pre-European Māori life certainly identify whānau, hapū and iwi as basic units of social organisation in pre-European Māori society (based as they were on kinship and particularly on descent from a common ancestor), Māori social and political relations were far more dynamic and flexible than is generally conveyed. First, iwi, hapū and whānau were not hermetically discrete social, cultural, and political entities inhabiting exclusively maintained bordered territories. Rather, they were complex constellations of lineages woven together by intermarriage, political alliance, and by migration and resettlement.

Because Māori descent groups were, and continue to be, ambilineal in nature-that is, they are based on descent through either male or female lines (or both), and because all of these genealogical links are 
retained-Māori have always been able to regard themselves as belonging to any number of potential descent groups (Mahuika 1992, 54). They could and frequently did "activate" their rights to the hapu and iwi of both parents by residing with different communities of which these descent groups were part at different times of their lives (Ballara 1991, 32). Furthermore, the ongoing process of intermarriage meant that many hapū did not necessarily regard themselves as belonging exclusively to one iwi: they had descent lines from several. There has always been the potential, therefore, for Māori to identify strongly with multiple hapū and iwi.

A hierarchical tribal system of government based on capitalist property rights was not only a useful device to simplify the acquisition of Māori land, it also served as a useful mechanism of social control as Māori resistance to land alienation gained momentum. It allowed the cultivation of indigenous "go betweens": tribal leaders co-opted within the machinery of the colonial state in order to maintain a maximum degree of political cohesion and prevent resisting hapu and iwi from undermining the emerging capitalist social relations of production. Furthermore, it proved, in the long term, a convenient political fiction because it provided a pragmatic solution to the many problems associated with developing a central administrative framework to control complex indigenous affairs. This model of Māori political organisation was eventually entrenched in legislation by successive governments who established statutory trust boards on tribal lines to facilitate dealings between central government and Māori (Ross 1998).

These static and hierarchical models formulated in the nineteenth century and perpetuated by both scholars and colonial officials have been challenged by those emphasising the role of the hapu as the effective, independent political unit of pre-European Māori society (Barnao 1998, 6). Certainly, in the eighteenth century, decision- 
making frequently took place at a much more localised level than the widely dispersed iwi that we are so familiar with today (Lian 1987, 454; Schwimmer 1968, 28-29). It is also clear that hapu remained the primary political, economic and social units of Māori society well into the twentieth century even after the general acceptance by Māori of iwi as an alternative representative body in some circumstances (Ballara 1991, 282).

The notion that only iwi are the appropriate entities to receive shares of the settlement proceeds (Levine 2001, 161) excludes those individuals and groups who can not trace their links to 'traditional iwi' or who seek comfort and solace in the urban context where they live. ${ }^{16}$ This represents a significant proportion of the Māori population. Indeed, at the 1996 Census, around the time of the debates over the allocation and distribution of the benefits of the fisheries settlement, 153,480 people of Māori descent (26 percent) either did not know the name of their iwi, or indicated they were affiliated to an iwi but did not give a response that Statistics New Zealand identified as a specific iwi. Breaking this down further, one in five Māori (19 percent) did not know the name of their iwi while a further 7 percent did not specify the iwi they belonged to. ${ }^{17}$

Rather than create institutional arrangements that actually relate to the contemporary reality of a considerable proportion of Māori society, the state has actively encouraged the re-tribalisation of Māori society. The Treaty of Waitangi Fisheries Commission, for instance,

\footnotetext{
${ }^{16}$ See Treaty of Waitangi Fisheries Commission, Ahu whakamua: The Treaty of Waitangi Fisheries Settlement: What it means for you-Summarising the Report for Agreement on the Allocation of Assets and Distribution of Benefits of the Treaty of Waitangi Fisheries Settlement, August 2002, p. 3.

${ }^{17}$ Statistics New Zealand (1999) Profile of Māori Descendants who did not know or did not specify an iwi, Wellington: Statistics New Zealand, p. 7.
} 
has set up a toll-free "iwi helpline" to assist those "de-tribalised" Māori to find their iwi. By 2006, a total of 102,366 people of Māori descent did not know their iwi. This represented a decrease of 9.1 percent since 1996. Nevertheless, these efforts to connect Māori with the appropriate iwi clearly entails a partisan view about the legitimacy of those Māori who identify themselves in hapū either in ethnic terms or as members of urban Māori communities. Through this process the state has effectively limited the way that Māori can express their identity in a contemporary context by categorising them into more convenient and allegedly authentic groupings. Failure to express contemporary Māori identity in these terms may ultimately damage the credibility of claimants involved in the Treaty settlement process.

\section{Conclusion}

One cannot understand the evolution of Mãori identities without acknowledging that they are an integral part of the web of social relationships that are themselves subject to change, redefinition and contestation. The negotiation and renegotiation of Māori identities involves claiming and resisting identities from within a set of prevailing discourses about the authenticity of particular indigenous categories. The social actors that articulate these discourses are themselves embedded in unequal sets of social, economic, and political relations.

The shifting nature of identity means that Māori individuals throughout the course of their lives can and do represent themselves differently depending on the particular time, space, and context. What we refer to as Māori identity therefore is principally a social process that expresses itself in the moving social boundaries and identities that indigenous people in Aotearoa/New Zealand, collectively and individually, draw around themselves in their relationships with others in the course of their everyday social lives. For this reason we 
cannot simply speak of Māori as a static group of people who share whakapapa (ancestry), culture, language, or other markers of difference. In order for Māori identity to be given meaning, the real or perceived differences of ancestry, culture and language need to be actually mobilised in everyday interactions with others. These dimensions, as Fenton $(1999,10)$ argues, are "...activated -or suppressed- in a wide variety of contexts."

While it is certainly the case that Māori individuals and groups have some degree of agency in the construction and maintenance of their collective and individual identities, people are, of course, not simply free to create or change their identities at will. Māori identities have been, and continue to be, negotiated and renegotiated in the context of the ongoing political, economic, and social subjugation of iwi, hapū, and urban Māori communities. They have also been constituted in the context of inequalities between Māori. As a result, particular narratives about what constitutes an "authentic" or "traditional" Māori identity have conflicting political implications for different groups of Māori in the present.

While the diversity of Māori lived experiences is more widely acknowledged than it once was, there is a tendency, nonetheless, to fall back on reified and simplistic notions of tradition, language, and culture as constituting an unchanging "authentic" essence of Māori identity. Rather than suggesting that those Māori who do not share all of these elements of culture are inauthentic or suffer from some degree of deprivation, it is important to acknowledge the diverse identities that result from the various experiences of being Māori in the many places in the world which Māori now live. This involves acknowledging the increasingly diverse circumstances in which Māori now find themselves. 


\section{References}

Calhoun, C. 'Social Theory and the Politics of Identity' In Social Theory and the Politics of Identity, edited by C. Calhoun, 9-36. Oxford: Blackwell Publishers, 1994.

Ballara, A. (1991), 'The Origins of Ngati Kahngunu', Unpublished Doctoral Dissertation, Victoria University of Wellington, 1991.

Barnao, P. 'Importance of Hapus [sic] stressed.' The Dominion, 27 May, 1998.

Brekhus, W.H. 'Trends in the Qualitative Study of Social Identities.' Sociology Compass 2, 3 (2008): 1063

Brewer, M. 'The Many Faces of Social Identity: Implications for Political Psychology.' Political Psychology, 22, 1 (2001): 115125.

Brubaker, R. and Cooper, F. 'Beyond 'Identity'. Theory and Society 29, 1 (2000): 1-47.

Calhoun, C. Critical Social Theory: Culture, History and the Challenge of Difference, Oxford: Blackwell, 1995.

Deaux, K. 'Social Identification.' In Social Psychology: Handbook of Basic Principles, edited by E.T. Higgins \& A. Kruglanski, 777798. NewYork: Guilford, 1996.

Eller, J.D. and Coughlan, R.M. (1993) 'The Poverty of Primordialism: The Demystification of Ethnic Attachments.' Ethnic and Racial Studies 16, 2 (1993).

Fenton, S. Ethnicity: Racism, Class and Culture. London: Macmillan Press, 1999.

Greenland, H. 'Māori Ethnicity as Ideology.' In Ngā Take: Ethnic Relations and Racism in Aotearoa/New Zealand, edited by P. Spoonley, D. Pearson, and C. Macpherson, Palmerston North: Dunmore Press, 1991.

Hall, S. 'Introduction: Who Needs Identity?' In Questions of Cultural 
Identity, edited by S. Hall and P. du Gay. London: Sage Publications, 1996.

Hogg, M.A., Terry, D.J. and White, K.M. 'A Tale of Two Theories: a Critical Comparison of Identity Theory with Social Identity Theory.' Social Psychology Quarterly, 58 (1995): 255-269. Jacobs, H. and Hirsh, B. Indigenous Land Tenure: Land Use in Alaska: Community Impacts of the Alaska Native Claims Settlement Act, Working Paper No. 16, North America Series, Land Tenure Center, University of Wisconsin -Madison, August 1998.

Levine, H. B. 'Can a Voluntary Organisation be a Treaty Partner? The Case of Te Whanau o Waipareira Trust.' Social Policy Journal of New Zealand 17 (2001): 161.

Lian, K.E.'Interpreting Māori History: A Case for a Historical Sociology.' The Journal of the Polynesian Society 96, 4 (1987).

Mahuika, A. 'Leadership: Inherited and Achieved.' In Te Ao Hurihuri: The World Moves On: Aspects of Māoritanga, edited by M. King. Auckland: Reed, 1992.

McIntosh, T. 'Contested Realities: Race, Gender and Public Policy in Aotearoa/New Zealand.' Paper prepared for the United Nations Research Institute for Social Development (UNRISD) Conference on Racism and Public Policy, Durban, South Africa, September 2001.

Melbourne, H. Maori Sovereignty: The Maori Perspective, Auckland: Hodder Moa Beckett, 1995.

Ngata, A. T. Rauru-nui-ä-Toi lectures and Ngati Kahungunu origin. Wellington: Victoria University, 1972.

Parsonson, A. (1992) 'The Challenge to Mana Māori.' In The Oxford History of New Zealand 2nd ed.Edited by G.W. Rice, 190-194. Auckland: Oxford University Press,1992.

Pearson, D. A Dream Deferred: The Origins of Ethnic Conflict in New Zealand, Wellington: Allen and Unwin, 1990. 
Peterson, R.A. 'In Search of Authenticity.' Journal of Management Studies 42 (2005): 1083-98.

Poata-Smith, E.S. Te Ahu. 'He Pōkeke Uenuku i Tu Ai: The Evolution of Contemporary Māori Protest.' In Ngā Patai: Racism and Ethnic Relations in Aotearoa/New Zealand, edited by P. Spoonley, D. Pearson, D. and C. Macpherson. Palmerston North: Dunmore Press, 1996.

Poata-Smith, E.S. Te Ahu. 'The Political Economy of Māori Protest Politics,' Unpublished Doctoral Thesis, University of Otago, 2001.

Poata-Smith, E.S. Te Ahu. 'The Treaty of Waitangi Settlement Process and the Changing Contours of Māori Identity. 'In The Waitangi Tribunal, edited by J. Hayward, and N.R. Wheen. Wellington: Bridget Williams Books, 2004.

Rangihau, J. 'Being Māori.' In Te Ao Hurihuri: The World Moves On: Aspects of Māoritanga edited by M. King. Auckland: Reed, 1992.

Robertson, C. 'Urban Maori 'out to destroy society'.' The Evening Post, April 19, 1997.

Ross, M. 'Hard Lessons Still As Legal Basis Rests On Fiction.' National Business Review, 18 September, 1998.

Said, E. Orientalism: Western Conceptions of the Orient, London: Penguin Books, 1995.

Schwimmer, E. 'The Aspirations of Contemporary Maori.' In The Maori People in the Nineteen-Sixties: a Symposium edited by E. Schwimmer. Auckland: Longman Paul, 1968.

Sharp, A. Justice and the Māori: Māori Claims in New Zealand Political Argument in the 1980s. Auckland: Oxford University Press, 1990.

Taonui, R. 'Whakapapa-Genealogy-What is whakapapa?' Te Arathe Encyclopedia of New Zealand, 2011. Accessed at, http://www.TeAra.govt.nz/en/whakapapa-genealogy/1 
Taonui, R. 'Ngā tuakiri hou - new Māori identities-New terms for a new world.' Te Ara-the Encyclopedia of New Zealand, 2011. Accessed at http://www.TeAra.govt.nz/en/nga-tuakiri-hounew-maori-identities/5

Te Rito, J.S. 'Whakapapa: A framework for understanding identity.' MAI Review, 2 (2007): 2.

Ward, A. 'Historical claims under the Treaty of Waitangi.' Journal of Pacific History 28, 2 (1993): 202.

William, H.A. Dictionary of the Māori Language $7^{\text {th }} \mathrm{ed}$. Wellington: GP Publications, 1992.

Williams, J.P. 'Authentic Identities: Straightedge Subculture, Music, and the Internet.' Journal of Contemporary Ethnography 35 (2006): 173-200. 